Revue musicale OICRM

\title{
Women in the Studio. Creativity, Control and Gender in Popular Music Sound Production, de Paula Wolfe
}

\section{Amandine Pras}

Volume 7, numéro 2, 2020

Fenêtre ouverte sur la médiation de la musique

URI : https://id.erudit.org/iderudit/1072424ar

DOI : https://doi.org/10.7202/1072424ar

Aller au sommaire du numéro

Éditeur(s)

Observatoire interdisciplinaire de création et recherche en musique (OICRM)

ISSN

2368-7061 (numérique)

Découvrir la revue

Citer ce compte rendu

Pras, A. (2020). Compte rendu de [Women in the Studio. Creativity, Control and Gender in Popular Music Sound Production, de Paula Wolfe]. Revue musicale OICRM, 7(2), 158-169. https://doi.org/10.7202/1072424ar d'utilisation que vous pouvez consulter en ligne.

https://apropos.erudit.org/fr/usagers/politique-dutilisation/ 


\section{Women in the Studio. Creativity, Control and Gender in Popular Music Sound Production, de Paula Wolfe New York, Routledge, 2019, 232 pages}

\section{Amandine Pras}

Mots clés: auteure-compositrice-interprète ; genre et musique ; industrie du numérique ; réalisation d'enregistrements ; studio privé.

\section{RENDRE HOMMAGE AUX RÉALISATRICES D'ENREGISTREMENTS}

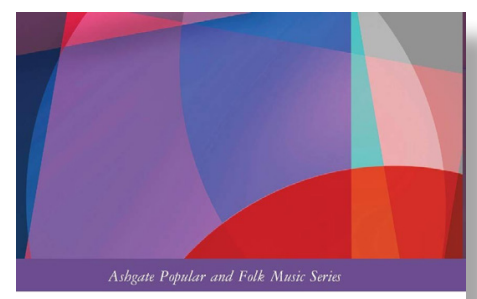

WOMEN IN THE STUDIO

CREATIITTY, CONTROL AND GENDER IN POPULAR MUSIC SOUND PRODUCTION

Paula Wolfe

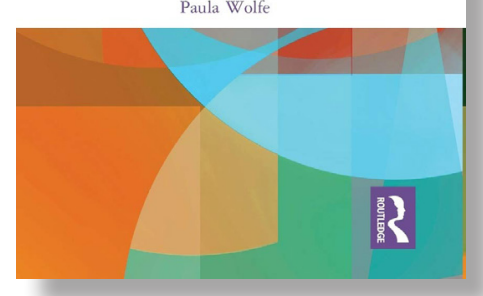

Lutter contre les déséquilibres et les inégalités des genres reste le plus gros défi de l'industrie des musiques populaires du début du $\mathrm{XXI}^{\mathrm{e}}$ siècle. Paula Wolfe nous offre une contribution empirique rare sur ce paradigme de production culturelle qui s'est récemment hissé au statut de sujet sensible dans le milieu académique. Son point de vue sur ce qui peut être perçu comme controversé s'inscrit dans une analyse profonde de la démographie et du contenu des discours lors de colloques, salons commerciaux et stages de formation organisés par l'industrie musicale britannique entre 2006 et 2018. Pour enrichir cette analyse, elle a mené à la même période deux études basées sur des entretiens qui soulignent les pratiques professionnelles de 30 femmes dans l'industrie européenne des musiques populaires. Inévitablement, sa triangulation de méthodes converge vers une différenciation et une discrimination systémiques des genres dans notre industrie.

Dans l'introduction (p. 1-26) de Women in the Studio, Wolfe mentionne qu'au début, recruter des femmes pour participer à sa recherche par l'intermédiaire des syndicats et des institutions du secteur musical s'est avéré infructueux, dû au faible nombre de professionnelles qui réussissent en suivant des chemins de carrière tout tracés. 
Dans le premier chapitre («The music industry and gender», p. 27-55), nous apprenons que les femmes n'ont obtenu que $6 \%$ des postes à haute responsabilité dans le secteur musical londonien. En ce qui concerne la production en studio, une récente étude Annenberg a dévoilé que les femmes ne représentent que $2 \%$ des réalisateurs d'enregistrements crédités sur les 600 chansons du prestigieux classement du magazine américain Billboard entre 2012 et 2017, et 0 \% des nominés aux prix Grammy dans la catégorie «Réalisateur de l'année » entre 2013 et $2018^{1}$. En outre, seulement deux des 652 réalisateurs crédités sur ces 600 chansons sont des femmes membres de groupes dits raciaux et ethniques sous-représentés. Ces chiffres renforcent la pertinence des efforts de Wolfe pour rendre compte des expériences de vie de ces réalisatrices qui persistent, malgré les barrières professionnelles et le " plafond de verre ».

Women in the Studio fournit aux lecteurs et aux lectrices une revue exhaustive et actualisée de la littérature académique sur la musique et l'équité des genres, centrée sur l'utilisation des technologies du studio. Le travail de Wolfe complète une documentation de plus en plus abondante sur la production musicale, mais qui a jusqu'à présent exclu les visions féministes. Pour rédiger ce compte rendu de lecture, j'ai donc privilégié une approche féministe, ce qui me conduit à argumenter mes propres pensées à partir de celles de l'auteure, plutôt que de m'en tenir à un résumé critique de ses idées.

\section{L'AUTONOMISATION COLLECTIVE POUR EMPÊCHER LA PROPAGATION DU PATRIARCAT}

Selon la thèse principale du livre, les technologies audionumériques permettent aux femmes de s'épanouir dans la production musicale en gardant le contrôle de leur son dans leur studio privé, jusqu'à ce qu'elles accèdent à un niveau de confiance en soi suffisant pour faire face au climat du studio d'enregistrement commercial qui est peu favorable à leur genre. Wolfe développe cette thèse dans le troisième chapitre ("Self-production, music technology and gender», p. 93-123). Elle y analyse l'expérience positive de 14 femmes qui ont su tirer profit de l'intimité de leurs propres installations pour exprimer leur voix intérieure lors de la réalisation de leurs projets d'auteures-compositrices-interprètes, au lieu d'obtempérer avec le paternalisme et le conformisme des grandes maisons de disque. Dans le quatrième chapitre ("New industry and gender », p. 124-150), l'auteure cite l'artiste-réalisatrice-productrice Nerina Pallo selon qui une artiste indépendante peut mieux contrôler son image dans les médias qu'une artiste signée dans une maison de disque. Le travail dans un studio privé apparaît alors comme la solution la plus réaliste pour que les auteures-compositrices-interprètes développent leurs compétences et promeuvent leur activité, avant d'exposer leur personne et leur art au milieu patriarcal de l'industrie musicale.

1 Voir Stacy L. Smith, Marc Choueiti et Katherine Pieper (2019), "Inclusion in the Recording Studio? Gender and Race/Ethnicity of Artists, Songwriters \& Producers across 600 Popular Songs from 2012-2018 ", Annenberg Inclusion Initiative, http://assets.uscannenberg.org/docs/aii-inclusion-recording-studio-2019.pdf (consulté le 17 juillet 2020). 
Je trace un parallèle entre cette solution solitaire et la situation due à la pandémie Covid-19, qui a forcé la plupart des réalisateurs d'enregistrements à compter sur les technologies audionumériques disponibles chez eux, tout en profitant de la possibilité de gérer leur emploi du temps professionnel autour de la garde de leurs enfants et des tâches domestiques. Wolfe est transparente dans les résultats de son étude sur l'origine de ses participantes, principalement blanches et issues des classes moyennes. Elle explique qu'un réalisateur d'enregistrements a besoin d' " autodétermination » pour poursuivre une carrière musicale, et que « l'autodétermination n'est pas juste une question de volonté, mais elle est aussi liée à des circonstances propices et à des qualités telles qu'une motivation viscérale, de la détermination et de la confiance en soi » (p. 45 ; ma traduction). La situation due à la pandémie covid-19 souligne à quel point une personne a besoin d'être professionnellement établie, socialement privilégiée et économiquement stable pour développer une carrière "à la maison ", quel que soit son genre.

Dans le cinquième chapitre ("Media representation and gender ", p. 151-179), Wolfe montre combien l'importance de l'autodétermination individuelle est renforcée dans un tableau qui présente des stratégies pour surmonter les conséquences de la dissociation systémique des genres dans la production musicale (tableau 5.1, p. 165). Je propose d'ajouter l'autonomisation collective à la fois comme stratégie efficace pour défier le statu quo et comme alternative à l'isolation des jeunes femmes qui souhaitent apprendre les métiers du studio. Pour illustrer ma proposition, je renvoie au groupe de femmes punks londoniennes The Slits qui ont défié les règles et les conventions de l'industrie à la fin des années 1970 par la sincérité de leur procédé créateur en studio et par la subversion de leur image médiatique ${ }^{2}$. Technophobes ou peu intéressées par l'apprentissage des technologies du studio (qui étaient analogiques à l'époque), elles ont réussi à trouver des réalisateurs et des ingénieurs du son (de sexe masculin) qui ont respecté leur vision artistique sans tomber dans le paternalisme. Le groupe a cependant rejeté un gérant (de sexe masculin) de tournée après l'autre. Après The Slits, chacune des quatre membres fondatrices a poursuivi sa vision artistique et son parcours de vie. Loin de renier leur passion individuelle ou leur autodétermination, je suggère que leur force collective leur a permis de percer et de supporter les agressions sexistes extrêmes auxquelles elles ont dû faire face, tout en réussissant à ne tomber dans aucun des pièges patriarcaux de l'industrie. À mon sens, collaborer avec des personnes qui adoptent une approche féministe de la création peut contrer l'effet le plus pervers du patriarcat pour les femmes : la compétition féminine.

\section{DES PROCÉDÉS D'IMPROVISATION POUR LIMITER LES COMPORTEMENTS TOXIQUES}

\section{DANS LE CONTRÔLE DU SON}

À la fin du deuxième chapitre ("Music production and gender », p. 56-92), Wolfe cite l'auteure-compositrice-réalisatrice Isabella Summers au sujet de la tâche principale

\footnotetext{
2 Voir Viv Albertine (2017), De fringues, de musique et de mecs, traduit de l'anglais par Anatole Muchnik,
} Paris, Buchet-Chastel. 
et neutre de genre du réalisateur d'enregistrements, laquelle consiste à " saisir les vibrations » dans le sens de « capturer les émotions qui émanent de l'interprétation de l'artiste» (p. 84 ; ma traduction). Wolfe soutient que le fait de positionner le réalisateur comme auteur unique de cette capture exclut le point de vue des femmes. Dans cette optique, certaines réalisatrices de son étude disent se sentir plus confortables avec l'idée d'être créditées comme coréalisatrices. Cette situation est complexe, car les réalisateurs d'enregistrements ont tendance à ne pas être crédités correctement pour leur travail, quel que soit leur genre ${ }^{3}$. Par exemple, réduire le travail du réalisateur à des manipulations sonores seules rend invisible leur capacité à "saisir les vibrations". Un réalisateur ne cherche pas à être crédité comme compositeur quand sa vision artistique influence la chanson ni comme interprète quand il encadre les prises de voix et qu'il monte les meilleures prises ensemble. À l'inverse, il est fréquent qu'un compositeur ou un interprète s'octroie le crédit de réalisateur ou de coréalisateur dès lors qu'il a exprimé ses commentaires sur le travail de réalisation. Je suppose donc que la réticence de certains réalisateurs à "lâcher prise " (p. 65) vient de la peur que leur travail ne soit pas reconnu s'ils en perdent le contrôle. Si cela s'avère juste, nous pourrions alors limiter les comportements masculins toxiques dans le contrôle du son en reconnaissant pleinement la contribution artistique des réalisateurs.

Dans une étude fondée sur des entretiens avec six réalisateur rice's renommé·e·s travaillant pour différents styles musicaux ${ }^{4}$, nous avons montré que leur plus haut niveau d'implication artistique, soit « collaborer avec les artistes », conduit au meilleur résultat artistique, mais exige beaucoup de "travail émotionnel " ${ }^{5}$ pour s'adapter à la sensibilité des artistes. Par comparaison, le niveau d'implication de " gérant », qui peut glisser vers des comportements autoritaires ou paternalistes, serait moins exténuant. Idéalement, l'interaction entre les réalisateurs et les artistes suivraient les principes de "l'art de la collaboration ${ }^{6}$, soit, par exemple, l'abolition des hiérarchies entre instrumentistes telle qu'elle a été introduite par les musiciens africains américains de jazz à la fin des années 1950 et dans les années 1960 " pour libérer » le jazz de sa réappropriation culturelle blanche ${ }^{7}$. Pour que "la composition improvisée " se révèle, un saxophoniste de jazz attend du batteur qu'il embauche que ce dernier

3 Voir Grace Brooks, Amandine Pras, Athena Elafros et Monica Lockett (à paraître), « Do We Really Want To Keep The Gate Threshold That High? ».

4 Voir Amandine Pras, Caroline Cance et Catherine Guastavino (2013), « Record Producers' Best Practices For Artistic Direction-From Light Coaching To Deeper Collaboration With Musicians ", Journal of New Music Research, vol. 42, nº 4, p. 381-395, https://www.tandfonline.com/doi/full/10.1080/0 9298215.2013.848903 (consulté le 17 juillet 2020).

5 Voir Allan Watson et Jenna Ward (2013), « Creating the Right 'Vibe'. Emotional Labour and Musical Performance in the Recording Studio ", Environment and Planning A, vol. 45, n 12, p. 2904-2918, https://journals.sagepub.com/doi/abs/10.1068/a45619 (consulté le 17 juillet 2020).

6 Voir Guerino Mazzola et Paul B. Cherlin (2009), Flow, Gesture, and Spaces in Free Jazz. Towards a Theory of Collaboration, Berlin, Springer Science \& Business Media.

$7 \quad$ Voir Philippe Carles et Jean-Louis Comolli (1971), Free Jazz Black power, Paris, Éditions Champ Libre. 
joue ce qu'il entend intérieurement au lieu de s'en tenir à assurer le beat ${ }^{8}$. De la même façon, pour que "la composition produite " se révèle, un auteur-compositeurinterprète pourrait attendre du réalisateur qu'il embauche de concevoir le son qu'il entend intérieurement au lieu d'appliquer des recettes techniques. Cependant, prendre le risque de combiner les voix intérieures de tous les agents impliqués dans la création nécessite que chacun d'eux abandonne son attachement à sa " signature sonore ", laquelle correspond à une certaine construction du vedettariat de l'industrie musicale. Pour que ce modèle fonctionne, professionnalisme, maturité et prise de conscience sont certainement plus utiles qu'avoir « la peau dure » (p. 67) de chaque côté de la vitre du studio.

\section{SAISIR LA VIBRATION DES VOIX DE FEMMES À PARTIR DU « REGARD FÉMININ »}

Deux paradoxes intéressants émergent vers la fin de l'ouvrage. À travers l'exemple de la musicienne-réalisatrice Isobel Campbell, qui enfreint les règles en faisant appel à un homme pour interpréter sa musique, Wolfe montre que c'est l'affichage de leur voix de femme qui conduit les auteures-compositrices-interprètes à être objectivées sexuellement et stéréotypées. En attendant, c'est chanter qui donne la plus grande opportunité aux femmes d'obtenir de la visibilité dans le secteur musical. L'autre paradoxe est que l'industrie émet des difficultés à reconnaître la légitimité des musiciennes-réalisatrices parce qu'elles assurent plusieurs rôles à la fois. Ironiquement, une idée reçue associe le multitâche aux femmes plutôt qu'aux hommes. Nous pouvons aussi penser aux femmes célèbres comme l'artiste-réalisatrice d'enregistrements et de films Laurie Anderson qui transcende confortablement les démarcations des mondes artistiques telles qu'elles ont été définies par des hommes.

Comme le mentionne Wolfe, réaliser de la musique électronique offre un refuge parfait aux femmes qui souhaitent éviter " l'objectivation de leur voix " et " l'incompréhension de leur rôle ». En effet : "Avec l'électronique, vous pouvez laisser l'humanité et le genre de côté. Il ne s'agit pas de transformer les femmes en hommes, mais de dissocier les femmes de leur genre » (Nik Void dans Awbi 2014 cité p. 166 ; ma traduction). Lire cette citation m'a rappelé la conclusion de l'ethnographie de Boden Sandstorm avec des femmes sonorisatrices aux États-Unis dans les années 1980 : "En tant que sonorisatrices dans un environnement essentiellement masculin, nous faisons l'expérience de la répartition des identités de genre. Nous sommes souvent perçues comme des personnes sans genre ${ }^{9}$ ». Malheureusement, il semblerait que la situation n'ait pas vraiment changé en 40 ans.

8 Amandine Pras (2015), " Irréductibles défenseurs de la composition improvisée à New York ", Études critiques en improvisation, vol. 10, $\mathrm{n}^{\circ} 2$, https://www.criticalimprov.com/index.php/csieci/article/ view/3341 (consulté le 17 juillet 2020). Intraduisible en français, le concept anglophone de beat, dans le context du jazz, inclue les notions de tempo, mesure et pulsation, ainsi que de groove, soit la déviation temporelle entre le rythme joué et la pulsation métronomique, et de swing, soit une subdivision inégale de la pulsation.

9 Boden Sandstrom (2000), «Women Mix Engineers and the Power of Sound ", dans Pirkko Moisala et Beverley Diamond (dir.), Music and Gender, Urbana, IL, University of Illinois Press, p. 300-301 ; ma traduction. 
En résumé, en tant que réalisatrices d'enregistrements nous devons nous isoler pour apprendre le métier, arrêter de chanter pour éviter qu'on nous stéréotype, cacher que nous pouvons assurer plusieurs rôles à la fois pour qu'on nous prenne au sérieux, et garder nos distances avec notre féminité pour survivre dans les studios sans être objectivées sexuellement, muselées ou marginalisées. Quel remède nous reste-t-il pour protéger notre pouvoir intérieur et notre créativité après tous ces sacrifices?

Quand j'étais au RMI [Revenu minimum d'insertion], je ne ressentais aucune honte d'être une exclue, juste de la colère. C'est la même en tant que femme : je ne ressens pas la moindre honte de ne pas être une super bonne meuf. En revanche, je suis verte de rage qu'en tant que fille qui intéresse peu les hommes, on cherche sans cesse à me faire savoir que je ne devrais même pas être là ${ }^{10}$.

Je suis d'accord avec Paul Thompson qui déclare dans un commentaire en préface de l'ouvrage que Women in the Studio est " essentiel pour quiconque travaille, joue ou pratique dans l'industrie musicale » (ma traduction). En effet, ce livre met au jour « le problème avec les réalisatrices d'enregistrements ». Étant donné la situation désespérée concernant l'équité de genre dans notre industrie, je voudrais encourager les auteurs, les compositeurs, les interprètes, les réalisateurs, les ingénieurs du son, le personnel des maisons de disques et les critiques musicaux à s'inspirer des livres féministes et des films réalisés avec un " regard féminin ${ }^{11}$ " pour surmonter le régime patriarcal de notre milieu professionnel, par exemple I Love Dick ${ }^{12}$, qui tourne en dérision la suprématie masculine blanche dans l'art moderne américain. Si des industries comme le cinéma ou la télévision autant dominés par des hommes blancs ont laissé la porte ouverte à des alternatives, nous devrions être capables de passer à autre chose dans la production musicale.

\section{REMERCIEMENTS}

Je voudrais remercier la poétesse Terri Witek, qui m'a rendu ma légitimité artistique et mon aptitude à « saisir les vibrations » après des années d'expérience en studio difficiles à New York, Montréal et Paris, ainsi que la pianiste et vocaliste Luciane Cardassi, qui m'a permis de garder une connexion saine avec le travail en studio depuis que j'ai obtenu un emploi académique à plein temps. Je dédie ce compte rendu de lecture à mes étudiantes de l'Université de Lethbridge, Laura Ferguson, Courtney McDermott, Kelsey Taylor et Alandra Woycenko, qui assurent tour à tour le rôle de la " seule femme » des cours de production en studio. Enfin, je remercie Athena Elafros, Grace Brooks, Monica Lockett et Adele Fournet pour leur collaboration et inspiration sur le sujet, et Emmanuelle Olivier pour sa relecture. Mes partenariats de recherche sur les inégalités et la discrimination sociale dan les studios d'enregistrement sont financés par le Conseil de recherches en sciences humaines (CRSH) du Canada.

10 Virginie Despentes (2006), King Kong Théorie, Paris, Grasset, p. 10.

11 Voir Iris Brey (2020), Le regard féminin. Une révolution à l'écran, Paris, Éditions de l'Olivier.

12 Chris Kraus (2016), I Love Dick, traduit de l'anglais par Alice Zeniter, Paris, Flammarion ; Joey Soloway et Sarah Gubbins (réal.) (2016-2017), I Love Dick, série télévisée, Amazon Video. 


\section{Women in the Studio. Creativity, Control and Gender in Popular Music Sound Production, by Paula Wolfe New York, Routledge, 2019, 232 pages}

\section{Amandine Pras}

Keywords: artist-producer; digital industry; home studio; music and gender; recording production; singer-songwriter.

Doing Justice to Women Producers

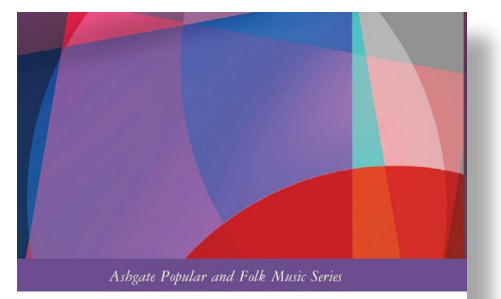

WOMEN IN THE STUDIO

CREATIVITY, CONTROL AND GENDER IN POPULAR MUSIC SOUND PRODUCTION

Paula Wolfe

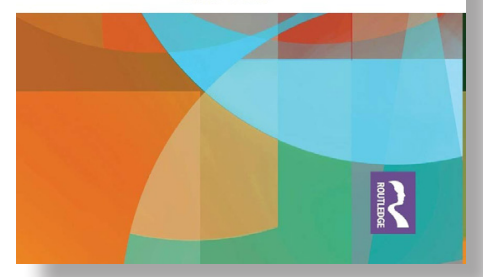

Reducing gender imbalance and inequalities remains the biggest challenge of the early $21 \mathrm{st}$ century popular music industry. Paula Wolfe offers a rare empirical contribution on this cultural production paradigm that has lately become a hot topic in academia. Her perspective on what may be perceived as a controversy draws upon an in-depth analysis of the demographics and gender-related speech content at music industry conferences, trade shows, and training events in the UK in 2006-2018. To enhance this analysis, she carried out two interview-based studies in the same period that highlight the work practices of 30 women professionals of the European popular music industry. Unavoidably, her triangulation of methods converges to provide evidence of systemic gendering and gender discrimination in the industry.

In the introduction (pp. 1-26) of Women in the Studio, Wolfe mentions that at first, recruiting women for her studies from the general unions and institutions was unfruitful because of the low number of women who succeed through the common career paths in the field. In the first chapter ("The music industry and gender," pp. 27-55), we learn that women hold only $6 \%$ of the senior music business positions 
in London. Regarding audio production, a recent Annenberg study reveals that women represent only $2 \%$ of the credited producers on the 600 songs of the 2012-2017 Billboard Hot 100 end-of-year charts, and $0 \%$ of the Grammy's "Producer of the year" nominees in 2013-2018. ${ }^{1}$ Moreover, only two out of the 652 credited producers on these 600 songs are women from underrepresented racial and ethnic groups. These harsh numbers underline the relevance of Wolfe's efforts to convey the life experience of women producers who persist in the field despite the gender barriers and "glass ceiling."

Women in the Studio provides the reader with an exhaustive and up-to-date review of the popular music and gender literature, with a focus on the use of studio technology. Wolfe's work supplements the growing body of the music production literature that has yet kept feminist visions silenced. I have thus opted for the style of feminist writers to review this book, which implies building on the author's arguments with some personal thoughts instead of summarizing her ideas and criticizing her achievements.

\section{Collective Empowerment to Prevent the Spread of Patriarchy}

According to the main thesis of Women in the Studio, digital audio technology enables women to thrive in music production by maintaining control of their sound in their home studio, at least until they gather enough self-confidence to face the unwelcoming gender climate of the commercial recording studio. Wolfe demonstrates this thesis in the third chapter ("Self-production, music technology and gender," pp. 93-123), which is based on the positive experiences of 14 women who used the intimacy of their own facilities to express their inner voice on their own terms for their solo singer-songwriter projects, as opposed to complying with the paternalism and conformism of major labels. In the fourth chapter ("New industry and gender," pp. 124-150), the author quotes artist-producer-label Nerina Pallo who testifies that an independent artist also has better control over who represents them in the media. Unfortunately, confinement in a home studio appears to be the most realistic solution for women singer-songwriters towards developing their skills and promoting their work before exposing themselves and their artistry to the patriarchal structure of the popular music industry.

I draw a parallel between this solitary solution and the covID-19 pandemic situation that has forced most producers to rely on their home-based digital audio technology while enjoying the possibility of managing their production schedule around childcare and other domestic necessities. Wolfe is transparent in her study report about the fact that her participants were mostly white and middle-class. She explains that producers need self-determination to pursue a music career, and that "self-determination is not just a question of will, but is linked to secure circumstances and qualities such

1 See Stacy L. Smith, Marc Choueiti and Katherine Pieper (2019), "Inclusion in the Recording Studio? Gender and Race/Ethnicity of Artists, Songwriters \& Producers across 600 Popular Songs from 2012-2018," Annenberg Inclusion Initiative, http://assets.uscannenberg.org/docs/aii-inclusion-recording-studio-2019.pdf (accessed 17 July 2020). 
as personal drive, determination and self-belief" (p. 45). In this view, the covid-19 situation highlights how well-established, or culturally privileged and economically secure one needs to be in order to pursue a music career from home, regardless of gender.

In the fifth chapter ("Media representation and gender," pp. 151-179), the importance of individual self-determination is reinforced in a table that provides strategies for overcoming the consequences of systemic gendering in music production (Table 5.1, p. 165). I propose to add collective empowerment as an effective strategy to challenge the status quo, and as an alternative to self-isolation for young women who aim to develop skills in music production. To illustrate my proposal, I refer to the female London-based punk band The Slits who confronted the rules and conventions of the industry in the late seventies from the genuineness of their studio production process to the subversion of their mediated image. ${ }^{2}$ Technophobe or unwilling to learn how to use studio technology (that was analog at the time), they successfully found (male) producers and engineers who respected their artistic vision without parenting them-however the band rejected one (male) manager after the other. After The Slits, each of the four founding members pursued her artistic vision and life path. My purpose is not to deny their individual passion and self-determination, I just point to how their collective strength allowed them to cut through and to cope with the extreme sexist aggressions that they had to face while succeeding in avoiding the patriarchal pitfalls of the industry. I thus suggest that collaborating with people who embrace a feminist approach of creation can counter the most perverse adverse effect of patriarchy for women, namely female competition.

\section{Improvisation Processes to Reduce Toxic Sound Control}

At the end of the second chapter ("Music production and gender," pp. 56-92), Wolfe quotes writer-producer Isabella Summers about the main and genderless producer task of "catching a vibe", in the sense of "capturing the emotion portrayed through an artist's performance" (p. 84). Wolfe claims that positioning the music producer as the individual author of this capture within a patriarchal framework excludes women producers. In this view, some women producers reported feeling more comfortable when being credited as co-producers. This case is complex because regardless of gender, music producers tend not to be properly acknowledged for their accomplishments. ${ }^{3}$ For instance, reducing the producer's job to sound manipulations makes their "vibe-catching" skills invisible. A producer does not request a composition credit when their artistic vision impacts on the song, nor do they get a performer credit when they coach a singer and edit the best takes together. In contrast, some composers and performers do not hesitate to credit themselves as the producer

2 See Viv Albertine (2014), Clothes, Clothes, Clothes. Music, Music, Music. Boys, Boys, Boys: A Memoir, New York, Thomas Dunne Books St Martin's Press.

3 See Grace Brooks, Amandine Pras, Athena Elafros and Monica Lockett (forthcoming), "Do We Really Want To Keep The Gate Threshold That High?". 
or a co-producer because they have provided feedback on the actual producer's work. I thus suppose that the unwillingness of some producers "to let go of them" (p. 65) comes from their fear of their artistic accomplishments to be denied if they loosen their control. If my supposition is true, then toxic masculinity in sound control could be attenuated by fully acknowledging the producer's contribution.

In an interview-based study, ${ }^{4}$ six renowned music producers working for different genres agreed that the highest level of producer's artistic involvement, i.e. "collaborating with the artists," leads to the best artistic result but requires a great deal of "emotional labour" ${ }^{5}$ to cope with artists' sensitivities. By comparison, a managerial producer position that may slip into an authoritarian or paternalistic behaviour is less exhausting. Ideally, the interaction between producers and artists would follow "art of collaboration" principles, ${ }^{6}$ e.g. the abolishment of the hierarchies among instrumentalists that was introduced by African American jazz performers in the late fifties and in the sixties "to free" jazz from its white cultural appropriation. ${ }^{7}$ For instance, a jazz saxophonist expects the drummer they hire to play what they are hearing internally instead of sticking to the beat for "improvised compositions" to unfold. ${ }^{8}$ Similarly, a singer-songwriter could expect the producer they hire to design the sound that they are hearing internally instead of applying technical recipes for the "produced compositions" to unfold. However, taking the risk of combining the inner voices of all creative parties requires everyone to abandon their attachment to their own "sound signature," another construct of the star system of the industry. For this model to function, professionalism, maturity and awareness would be more useful than "thick skins" (p. 67) on both sides of the studio glass window.

\section{Catching the Vibe of Female Voices from “The Female Gaze”}

Two interesting paradoxes emerge toward the end of the book. Through the example of producer Isobel Campbell who broke the rules by using a male vocalist to perform her music, Wolfe emphasizes that the display of the female voice is what causes women songwriters to be sexually objectified and stereotyped. At the same time, singing is the role that gives women the highest chance to reach visibility in

4 See Amandine Pras, Caroline Cance and Catherine Guastavino (2013), "Record Producers' Best Practices For Artistic Direction-From Light Coaching To Deeper Collaboration With Musicians," Journal of New Music Research, vol. 42, no 4, pp. 381-395, https://www.tandfonline.com/doi/full/10.1080/092982 15.2013.848903 (accessed 17 July 2020).

5 See Allan Watson and Jenna Ward (2013), "Creating the Right 'Vibe.' Emotional Labour and Musical Performance in the Recording Studio," Environment and Planning A, vol. 45, n 12, pp. 2904-2918, https://journals.sagepub.com/doi/abs/10.1068/a45619 (accessed 17 July 2020).

6 See Guerino Mazzola and Paul B. Cherlin (2009), Flow, Gesture, and Spaces in Free Jazz. Towards a Theory of Collaboration, Berlin, Springer Science \& Business Media.

$7 \quad$ See Philippe Carles and Jean-Louis Comolli (2015), Free Jazz/Black Power, translated from French by Patricia De Millo, Jackson, Ms, University Press of Mississippi.

8 See Amandine Pras (2015), "Irréductibles défenseurs de la composition improvisée à New York," Études critiques en improvisation, vol. 10, $\mathrm{n}^{\circ}$ 2, https://www.criticalimprov.com/index.php/csieci/article/ view/3341 (accessed 17 July 2020). 
music. The other paradox is the fact that the industry has difficulties taking women artist-producers seriously because they are multitasking. Ironically, it is a common belief that women are much better than men at multitasking. We can also think of famous women such as artist-producer and film director Laurie Anderson who have comfortably transcended the art world boundaries that have been defined by men.

As Wolfe mentions, producing electronic music is the perfect refuge for women who wish to avoid "voice objectification" and "role misunderstanding." Indeed: "With electronics you can strip away any humanity or gender. It's not about turning female into male gender but actually turning female into non-gender" (Nik Void in Awbi 2014, cited p. 166). Reading this quote reminded me of the conclusion reached by Boden Sandstorm in her ethnography of women live engineers in the USA in the eighties: "As women mix engineers in a predominantly male environment, we experienced the breakdown of gender identities. We were often viewed as genderless." 9 Unfortunately, it seems that this situation has not much changed in 40 years.

In summary, as women producers, we have to self-isolate to learn our skills, stop singing to avoid gendered representation, hide that we can multitask to be perceived as experts, and distance ourselves from our womanhood to survive working in a studio without being sexually objectified, stereotyped, silenced, or marginalized. What is the remedy to protect our inner power and creativity throughout all these sacrifices?

When I was on unemployment [benefit] I was not ashamed of being a social outcast. Just furious. It's the same thing for being a woman: I am not remotely ashamed of not being a hot sexy number but I am livid that - as a girl who doesn't attract men-I am constantly made to feel as if I shouldn't even be around. ${ }^{10}$

I agree with Paul Thompson who stated in his endorsement that Women in the Studio is "essential for anyone working, playing or practicing within the music industry." Indeed, this book draws "the problem with women producers" out. Given the hopeless gender disparity in our industry, I would like to encourage composers, performers, producers, audio engineers, label staff, and music critics to find some inspirations from feminist books and "female gaze" 11 film productions to overcome the patriarchal establishment of our field, e.g. ILove Dick ${ }^{12}$ that mocks white masculine supremacy in American modern art. If white-male-dominated fields like cinema and TV productions left the door ajar for alternatives, we should also be able to move on in music production.

9 Boden Sandstrom (2000), "Women Mix Engineers and the Power of Sound," in Pirkko Moisala and Beverley Diamond (eds.), Music and Gender, Urbana, IL, University of Illinois Press, p. 300-301.

10 Virginie Despentes (2010), King Kong Theory, translated from French by Stéphanie Benson, New York, The Feminist Press At The City University of New York.

11 See Iris Brey (2020), Le regard féminin. Une révolution à l'écran, Paris, Éditions de l'Olivier.

12 Chris Kraus (1997), I Love Dick, Los Angeles, Semiotext(e); Joey Soloway and Sarah Gubbins (dir.) (2016-2017), I Love Dick, TV Series, Amazon Video. 


\section{ACKNOWLEDGEMENTS}

I wish to acknowledge poet Terri Witek who made me feel artistically legitimate with my "catching-vibe skills" after years of de-gendering studio experiences in New York, Montreal and Paris, as well as pianist and vocalist Luciane Cardassi who has enabled me to keep a healthy connection with studio work since I started working full time in academia. I dedicate this book review to my University of Lethbridge female students, namely Laura Ferguson, Courtney McDermott, Kelsey Taylor, and Alandra Woycenko, who alternatively take the role of "the only woman" in studio production classes. Finally, I would like to thank Athena Elafros, Grace Brooks, Monica Lockett, and Adele Fournet for their collaboration and inspiration on this topic, and Terri Hron for her review of an earlier draft. My research partnerships about inequalities and social discrimination in the recording studio are supported by The Social Sciences and Humanities Research Council of Canada (SSHRC). 